\title{
Kordiimonas lacus sp. nov., isolated from a ballast water tank, and emended description of the genus Kordiimonas
}

\author{
Correspondence \\ Xue-Wei Xu \\ xuxw@sio.org.cn
}

\author{
Xue-Wei Xu, ${ }^{1,2}$ Ying-Yi Huo, ${ }^{3}$ Xue-Dong Bai, ${ }^{3,4}$ Chun-Sheng Wang, ${ }^{1,2}$ \\ Aharon Oren, ${ }^{5}$ Sui-Yan $\mathrm{Li}^{4}$ and $\mathrm{Min} \mathrm{Wu}^{3}$ \\ ${ }^{1}$ Laboratory of Marine Ecosystem and Biogeochemistry, State Oceanic Administration, Hangzhou \\ 310012, PR China \\ ${ }^{2}$ Second Institute of Oceanography, State Oceanic Administration, Hangzhou 310012, PR China \\ ${ }^{3}$ College of Life Sciences, Zhejiang University, Hangzhou 310058, PR China \\ ${ }^{4}$ School of Life Science and Engineering, Southwest Jiaotong University, Chengdu 610031, PR \\ China \\ ${ }^{5}$ Institute of Life Sciences, and the Moshe Shilo Minerva Center for Marine Biogeochemistry, The \\ Hebrew University of Jerusalem, Jerusalem 91904, Israel
}

Ballast water is essential for ships to maintain stability and safety at sea when sailing without cargo. When the water is discharged, sediments and biofilm from the ship's ballast water tanks can release invasive aquatic species to coastal regions. Micro-organisms have been largely ignored in ballast water research (Drake et al., 2007). The interesting environment of ballast water tanks has rarely been explored for the presence of novel species, and little is known about the potential significance of ship-mediated transfer of these micro-organisms. Here we present a polyphasic study describing a novel Kordiimonas strain isolated from a sediment sample collected from a ship's ballast water tank. The genus Kordiimonas, belonging to the order

The GenBank/EMBL/DDBJ accession number for the 16S rRNA gene sequence of strain S3-22 $2^{\top}$ is FJ847942.

Four supplementary figures and a supplementary table are available with the online version of this paper.
Kordiimonadales within the class Alphaproteobacteria, was proposed by Kwon et al. (2005). At the time of writing, Kordiimonas gwangyangensis was the sole described species within the order Kordiimonadales.

The sediment sample was collected from the ballast water tank of a commercial ship arriving at Zhoushan, Zhejiang province, China, in November 2007, and was stored in darkness at $4{ }^{\circ} \mathrm{C}$ until micro-organisms were isolated in February 2008. Approximately $100 \mathrm{mg}$ sediment subsample was incubated for $24 \mathrm{~h}$ in ZoBell medium, which contained (per l distilled water) $19.45 \mathrm{~g} \mathrm{NaCl}, 8.8 \mathrm{~g} \mathrm{MgCl}_{2}$, $3.24 \mathrm{~g} \mathrm{Na}_{2} \mathrm{SO}_{4}, 1.8 \mathrm{~g} \mathrm{CaCl}_{2}, 0.55 \mathrm{~g} \mathrm{KCl}, 0.16 \mathrm{~g} \mathrm{NaHCO}_{3}$, $0.1 \mathrm{~g}$ ferric citrate pentahydrate, $0.08 \mathrm{~g} \mathrm{KBr}, 34 \mathrm{mg} \mathrm{SrCl}_{2}$, $22 \mathrm{mg} \mathrm{H}_{3} \mathrm{BO}_{3}, 4.0 \mathrm{mg} \mathrm{Na}_{2} \mathrm{SiO}_{3}, 2.4 \mathrm{mg} \mathrm{NaF}, 1.6 \mathrm{mg}$ $\mathrm{NH}_{4} \mathrm{NO}_{3}, 8.0 \mathrm{mg} \mathrm{Na} \mathrm{PO}_{4}, 5.0 \mathrm{~g}$ peptone (BD) and $1.0 \mathrm{~g}$ yeast extract (BD), pH 7.4 (ZoBell, 1941). The liquid was plated on ZoBell agar plates using a tenfold dilution series. 
After 3 days of aerobic inoculation at $30{ }^{\circ} \mathrm{C}$, a light-yellow colony, designated $\mathrm{S} 3-22^{\mathrm{T}}$, was picked. The strain was purified by repeated restreaking; purity was confirmed by the uniformity of colony morphology. Unless otherwise stated, strain $\mathrm{S} 3-22^{\mathrm{T}}$ was maintained on marine agar 2216 (MA; BD) at $35{ }^{\circ} \mathrm{C}$.

Optimal conditions for growth were determined by using marine broth $2216(\mathrm{MB})$ with different $\mathrm{NaCl}$ concentrations $(0,0.5,1.0,1.5,2.0,3.0,5.0,7.5,10.0,15.0$ and $20.0 \%, \mathrm{w} / \mathrm{v})$. The $\mathrm{pH}$ range for growth was determined by adding MES ( $\mathrm{pH}$ 5.0-6.0), PIPES ( $\mathrm{pH}$ 6.5-7.0), Tricine ( $\mathrm{pH} 7.5-8.5$ ) or CAPSO ( $\mathrm{pH} 9.0-10.5)$ to MB at concentrations of $25 \mathrm{mM}$. The temperature range for growth was determined by incubating at $4,10,15,18,25,30,37,43$ and $48{ }^{\circ} \mathrm{C}$. Cell motility and morphology were examined by optical microscopy (BX40; Olympus) and transmission electron microscopy (JEM-1230; JEOL).

Single-carbon-source assimilation tests were performed using basal medium (BM). The corresponding filtersterilized sugar $(0.2 \%)$, alcohol $(0.2 \%)$, organic acid $(0.1 \%)$ or amino acid $(0.1 \%)$ was added to liquid medium. The BM (Mikhailov et al., 2006) contained $\left(1^{-1}\right.$ distilled water) $1.0 \mathrm{~g} \mathrm{NH}_{4} \mathrm{Cl}, 0.044 \mathrm{~g} \mathrm{~K}_{2} \mathrm{HPO}_{4}, 0.028 \mathrm{~g}$ $\mathrm{FeSO}_{4} \cdot 7 \mathrm{H}_{2} \mathrm{O}, 500 \mathrm{ml}$ artificial seawater and $100 \mathrm{ml}$ Tris/ $\mathrm{HCl}(1 \mathrm{M}, \mathrm{pH} 7.5)$. The artificial seawater contained $\left(1^{-1}\right.$ distilled water) $23.4 \mathrm{~g} \mathrm{NaCl}, 24.6 \mathrm{~g} \mathrm{MgSO}_{4} .7 \mathrm{H}_{2} \mathrm{O}, 1.5 \mathrm{~g}$ $\mathrm{KCl}$ and $2.9 \mathrm{~g} \mathrm{CaCl}_{2}$. Acid production was tested using modified marine oxidation-fermentation (MOF) medium supplemented with $1.0 \%$ sugars or alcohols (Leifson, 1963; $\mathrm{Xu}$ et al., 2008). Sensitivity to antimicrobial agents was determined on MA for at least 3 days. Oxidase and catalase activities, $\mathrm{H}_{2} \mathrm{~S}$ production, nitrate reduction and the ability to hydrolyse agar, casein, gelatin, starch and Tweens 20,40, 60 and 80 were assessed according to Dong \& Cai (2001). Additional enzyme activities and biochemical characteristics were determined using API 20E, API 20 NE and API ZYM kits (bioMérieux).

Quinones were extracted with chloroform/methanol $(2: 1$, $\mathrm{v} / \mathrm{v})$ from freeze-dried cells. The extracts were filtered and evaporated to near dryness and then redissolved in chloroform/methanol $(2: 1, \mathrm{v} / \mathrm{v})$. The fraction was analysed using an LC-MS spectrometer [Column Zorbax-ODS $(4.6 \times 250 \mathrm{~mm})$ with methanol/2-propanol $(4: 1, \mathrm{v} / \mathrm{v})$ as solvent at a flow rate of $1.5 \mathrm{ml} \mathrm{min}^{-1}$ (Grossi et al., 1992)]. The HPLC (Agilent 1200) was coupled to a Finnigan LCQ Deca XP Plus ion trap mass spectrometer (Thermo). Fatty acid methyl esters obtained from cells grown on MA for $48 \mathrm{~h}$ at $35^{\circ} \mathrm{C}$ were analysed by GC/MS (Kuykendall et al., 1988). Polar lipids were extracted using a chloroform/ methanol system and separated by two-dimensional TLC using silica gel $60 \mathrm{~F}_{254}$ aluminium-backed thin-layer plates (Merck) (Kates, 1986). The solvent systems chloroform/ methanol/water $(65: 24: 4$, by vol.) in the first dimension and chloroform/glacial acetic acid/methanol/water $(80: 12: 15: 4$, by vol.) in the second dimension were used. Separated components were visualized by treating the plates with $10 \%(\mathrm{w} / \mathrm{v})$ molybdatophosphoric acid followed by heating at $150{ }^{\circ} \mathrm{C}$ for $5 \mathrm{~min}$. Glycolipids were detected by spraying the plate with $0.5 \%(\mathrm{w} / \mathrm{v}) \alpha$-naphthol in methanol/water $(1: 1)$ and then with sulfuric acid/ethanol (1:1) following by heating at $120{ }^{\circ} \mathrm{C}$ for $5 \mathrm{~min}$; phospholipids were detected with Zinzadze reagent. Genomic DNA was obtained by using the method described by Marmur (1961). Purified DNA was hydrolysed with P1 nuclease and nucleotides were dephosphorylated with calf intestine alkaline phosphatase; the DNA $\mathrm{G}+\mathrm{C}$ content of the resulting deoxyribonucleosides was determined by reversed-phase HPLC and calculated from the ratio of deoxyguanosine $(\mathrm{dG})$ and thymidine $(\mathrm{dT})$ (Mesbah \& Whitman, 1989).

The 16S rRNA gene was amplified and analysed as described previously (Xu et al., 2007). PCR products were cloned into vector pMD 19-T (TaKaRa) and then sequenced to determine the almost-complete sequence of the 16S rRNA gene. The sequence was compared with closely related sequences of reference organisms from the FASTA and EzTaxon service (Chun et al., 2007). Similar sequences were aligned using the PHYDIT 3.1 program (Jeon et al., 2005). Phylogenetic trees were constructed by the neighbourjoining (Saitou \& Nei, 1987) and maximum-parsimony (Fitch, 1971) methods with the MEGA 4 program package (Tamura et al., 2007) and the maximum-likelihood method (Felsenstein, 1981) with the PHYLIP $3.6 \mathrm{a} 3$ software package. Evolutionary distances were calculated according to the algorithm of Kimura's two-parameter model (Kimura, 1980) for the neighbour-joining method.

Cells of strain $\mathrm{S} 3-22^{\mathrm{T}}$ were Gram-negative rods, approx. $0.5-0.8 \mu \mathrm{m}$ wide and 3.0-6.0 $\mu \mathrm{m}$ long. Cells were motile by means of flagella (Supplementary Fig. S1, available in IJSEM Online). Strain S3-22 $2^{\mathrm{T}}$ was able to hydrolyse aesculin, gelatin, starch and Tweens $20,40,60$ and 80 and to utilize more than 20 carbon sources including glycerol, glucose and L-glutamine. The results indicated that the isolate could grow well in seawater containing mixed soluble organic materials. Phenotypic characteristics of strain $\mathrm{S} 3-22^{\mathrm{T}}$ are given in the species description. A comparison of the phenotypic properties of strain $\mathrm{S} 3-22^{\mathrm{T}}$ and K. gwangyangensis JCM $12864^{\mathrm{T}}$ is shown in Table 1.

The almost-complete 16S rRNA gene sequence (1419 nt) of strain $\mathrm{S} 3-22^{\mathrm{T}}$ showed the highest sequence similarity $(96.1 \%)$ to that of the type strain of $K$. gwangyangensis and less than $91.0 \%$ sequence similarity to sequences from other recognized species. The $16 \mathrm{~S}$ rRNA gene sequence divergence between strain $\mathrm{S} 3-22^{\mathrm{T}}$ and the type strain of $K$. gwangyangensis exceeded $3 \%$, an accepted value for the distinction of different genomic species (Stackebrandt \& Goebel, 1994). Phylogenetic analysis based on 16S rRNA gene sequences showed that strain $\mathrm{S} 3-22^{\mathrm{T}}$ formed a clade adjacent to the type strain of $K$. gwangyangensis with a high bootstrap resampling value (100\% by the neighbour-joining method) (Fig. 1). Trees based on the maximum-parsimony and maximum-likelihood methods are available as Supplementary 
Table 1. Differentiating characteristics between strain S3-22 ${ }^{\top}$ and $K$. gwangyangensis JCM $12864^{\top}$

Data were obtained in this study under identical growth conditions. Both strains are positive for catalase, oxidase and hydrolysis of starch and Tween 80 and negative for arginine dihydrolase, lysine and ornithine decarboxylases, tryptophan deaminase and urease. Neither strain produces $\mathrm{H}_{2} \mathrm{~S}$ or indole. For both strains, the following compounds are utilized as sole carbon and energy sources: acetate, L-alanine, L-arginine, L-asparagine, L-aspartate, cellobiose, glucose, L-glutamine, L-glutamate, glycerol, L-histidine, myo-inositol, malate, maltose, L-ornithine, D-salicin, L-serine, trehalose and L-tyrosine. Acid is produced by both strains from cellobiose, glucose, myoinositol, maltose and trehalose. Both strains are susceptible to ( $\mu \mathrm{g}$ per disc, unless indicated) chloramphenicol (30), neomycin (30), novobiocin (30), penicillin G (10 IU), rifampicin (5) and streptomycin (10). In API ZYM tests, both strains are positive for acid and alkaline phosphatases, $N$-acetyl- $\beta$-glucosaminidase, $\alpha$-chymotrypsin, esterase (C4), esterase lipase (C8), leucine arylamidase, naphthol-AS-BI-phosphohydrolase and trypsin. +, Positive; -, negative; w, weakly positive.

\begin{tabular}{|c|c|c|}
\hline Characteristic & $\begin{array}{l}\text { Strain } \\
S 3-22^{T}\end{array}$ & $\begin{array}{l}\text { K. gwangyangensis } \\
\text { JCM } 12864^{\mathrm{T}}\end{array}$ \\
\hline \multicolumn{3}{|l|}{ Utilization of: } \\
\hline Gluconate & + & - \\
\hline Malonate & $\mathrm{w}$ & - \\
\hline Mannose & - & + \\
\hline D-Phenylalanine & - & + \\
\hline $\begin{array}{l}\text { Acid production from } \\
\text { mannose }\end{array}$ & - & + \\
\hline \multicolumn{3}{|l|}{ Sensitivity to ( $\mu$ g per disc): } \\
\hline Nitrofurantoin (300) & + & - \\
\hline Tobramycin $(10)$ & + & - \\
\hline \multicolumn{3}{|l|}{ API ZYM results } \\
\hline Cystine arylamidase & - & + \\
\hline Lipase $(\mathrm{C} 14)$ & - & $\mathrm{W}$ \\
\hline$\alpha$-Mannosidase & - & + \\
\hline DNA G $+\mathrm{C}$ content $(\mathrm{mol} \%)$ & 54.9 & $55.6^{\star}$ \\
\hline
\end{tabular}

${ }^{\star}$ Kwon et al. (2005) reported a value of $39.3 \mathrm{~mol} \%$.

Figs S2 and S3. Glycolipid analysis indicated that strain S3-22 ${ }^{\mathrm{T}}$ and $K$. gwangyangensis JCM $12864^{\mathrm{T}}$ contained the same four glycolipids (GL1-GL4) but that the latter possessed an additional glycolipid (GL5) (Supplementary Fig. S4). Phospholipid analysis revealed that both contained large amounts of phosphatidylglycerol (identification based on location on the TLC plate, the presence of phosphate and the absence of sugar moieties). This characteristic is shared with members of the genera Caulobacter, Brevundimonas, Maricaulis and Hyphomonas, which belong to the order Caulobacterales, the closest neighbour of the order Kordiimonadales in phylogenetic trees (Abraham et al., 1999). An in-depth study of the structure of the polar lipids found in the genus Kordiimonas is recommended in view of the diversity of lipids in phylogenetically related groups (Abraham et al., 1997, 1999; Poindexter, 2005), but is outside the scope of this paper. The major fatty acids of strain $\mathrm{S} 3-22^{\mathrm{T}}$ were iso- $\mathrm{C}_{17: 1} \omega 9 c$, iso- $\mathrm{C}_{15: 0}, \mathrm{C}_{16: 1} \omega 7 c$ and/or iso- $\mathrm{C}_{15: 0} 2$ $\mathrm{OH}, \mathrm{C}_{16: 0}$, iso- $\mathrm{C}_{17: 0}$ and $\mathrm{C}_{18: 1} \omega 7 c$, with hydroxy fatty acids iso- $\mathrm{C}_{17: 0} 3-\mathrm{OH}$ and $\mathrm{C}_{16: 0} 3-\mathrm{OH}$. Branched fatty acids are seldom found in alphaproteobacteria, but high contents of iso- and anteiso-branched fatty acids were reported in $K$. gwangyangensis (Kwon et al., 2005) and in Croceicoccus marinus (Xu et al., 2009). The content of iso-branched fatty acids of strain $\mathrm{S} 3-22^{\mathrm{T}}(56.3 \%)$ was less than that of $K$. gwangyangensis JCM $12864^{\mathrm{T}}$ (68.1\%) (Supplementary Table S1). Strain S3 $-22^{\mathrm{T}}$ and K. gwangyangensis JCM $12864^{\mathrm{T}}$ could be differentiated by different reactions in tests for utilization of gluconate, malonate, mannose and D-phenylalanine as sole carbon and energy sources. Further differences included formation of acid from mannose (negative for strain $\mathrm{S} 3-22^{\mathrm{T}}$ ), sensitivity to nitrofurantoin and tobramycin for strain $\mathrm{S} 3-22^{\mathrm{T}}$ and several enzyme activities (Table 1).

Ubiquinone Q-10 is found in most members of the Alphaproteobacteria (Dadhwal et al., 2009). LC-MS analysis revealed that the predominant quinone of strain $\mathrm{S} 3-22^{\mathrm{T}}$ and K. gwangyangensis JCM $12864^{\mathrm{T}}$ was Q-10. The data from the control strains, Escherichia coli K-12 (Q-8) and Zhangella mobilis CGMCC $1.7002^{\mathrm{T}}$ (Q-10), were in agreement with data from the literature. The $\mathrm{G}+\mathrm{C}$ content of DNA of strain S3 $-22^{\mathrm{T}}$ was $54.9 \pm 0.3 \mathrm{~mol} \%$, as determined by HPLC. This value is much higher than that reported for K. gwangyangensis (39.3 mol\%; Kwon et al., 2005). We therefore tested K. gwangyangensis JCM $12864^{\mathrm{T}}$ as well, and found a value of $55.6 \pm 0.3 \mathrm{~mol} \%$. E. coli K-12, Piscibacillus halophilus DSM $21622^{\mathrm{T}}$, Oceanobacillus oncorhynchi subsp. incaldanensis DSM $16557^{\mathrm{T}}$ and Sphingomonas melonis DSM $14444^{\mathrm{T}}$, included as controls, gave values of 47.6, 38.7, 35.5 and $67.1 \mathrm{~mol} \%$, respectively, being close to values reported in the literature. We therefore conclude that the respiratory quinone profile and the $\mathrm{G}+\mathrm{C}$ content published previously for $K$. gwangyangensis may be incorrect.

Based on the phenotypic differentiation (Table 1) and genotypic data presented above, we consider that strain S3$22^{\mathrm{T}}$ represents a novel species of the genus Kordiimonas, for which the name Kordiimonas lacus sp. nov. is proposed.

\section{Emended description of Kordiimonas Kwon et al. 2005}

In addition to the characteristics reported by Kwon et al. (2005), the following properties are observed. The G+C content of the DNA varies between 54 and $56 \mathrm{~mol} \%$. The predominant quinone is Q-10. The polar lipid profile consists of the major components phosphatidylglycerol and an unidentified glycolipid and trace amounts of three unidentified glycolipids. The major fatty acids are iso$\mathrm{C}_{17: 1} \omega 9 c$, iso- $\mathrm{C}_{15: 0}$ and $\mathrm{C}_{16: 1} \omega 7 c$ and/or iso- $\mathrm{C}_{15: 0} 2-\mathrm{OH}$.

\section{Description of Kordiimonas lacus sp. nov.}

Kordiimonas lacus (la'cus. L. gen. n. lacus of a lake or any large body of water, of a tank, referring to the isolation of the type strain from a ballast water tank). 


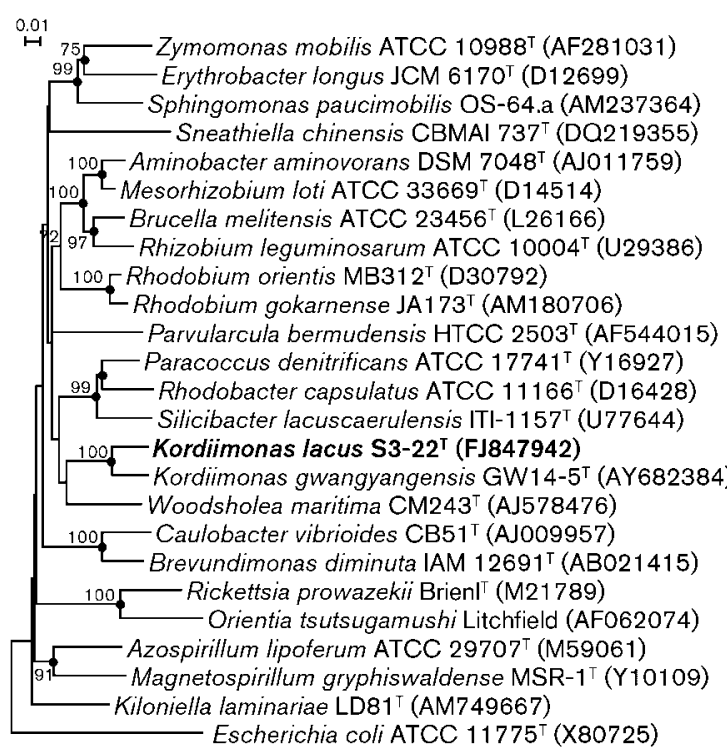

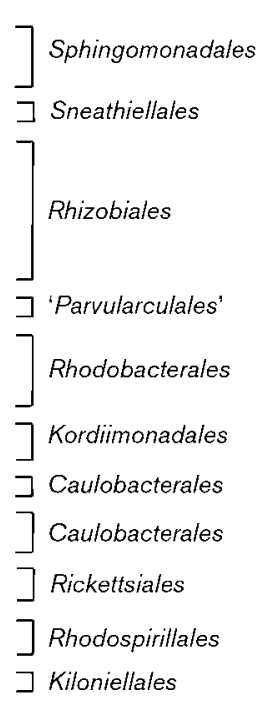

Fig. 1. Neighbour-joining tree based on $16 \mathrm{~S}$ rRNA gene sequences, showing the phylogenetic relationships of strain $\mathrm{S} 3-22^{\top}$ and related taxa. Bootstrap values are percentages based on 1000 replicates; only values $>70 \%$ are shown. Bar, 0.01 substitutions per nucleotide position. Filled circles indicate nodes recovered with bootstrap values $>70 \%$ in the maximum-parsimony tree. Trees based on the maximum-parsimony and maximum-likelihood methods are available as Supplementary Figs S2 and S3.
Gram-negative and motile by means of flagella. Cells are straight to slightly curved rods $(0.5-0.8 \mu \mathrm{m}$ wide and $3.0-$ $6.0 \mu \mathrm{m}$ long) with rounded ends. Colonies on MA are 1$2 \mathrm{~mm}$ in diameter, smooth, circular with regular borders and light-yellow after $72 \mathrm{~h}$. Growth is observed at $0.5-$ $10.0 \%(\mathrm{w} / \mathrm{v}) \mathrm{NaCl}$ with optimum growth at $2.0-3.0 \%$. The $\mathrm{pH}$ and temperature ranges for growth are $\mathrm{pH} 6.0-9.0$ and $10-43{ }^{\circ} \mathrm{C}$ (optimum growth at $\mathrm{pH} 7.0$ and $30-37{ }^{\circ} \mathrm{C}$ ). Positive for oxidase and catalase. Aesculin, gelatin, starch and Tweens 20, 40, 60 and 80 are hydrolysed. Agar and casein are not hydrolysed. $\mathrm{H}_{2} \mathrm{~S}$ is produced from thiosulfate. Voges-Proskauer reaction is positive. Negative for arginine dihydrolase, glucose fermentation, indole production, lecithinase, lysine and ornithine decarboxylases, ONPG (o-nitrophenyl $\beta$-D-galactopyranoside) test, tryptophan deaminase and urease. The following constitutive enzyme activities are detected in API ZYM tests: acid and alkaline phosphatases, $N$-acetyl- $\beta$-glucosaminidase, $\alpha$-chymotrypsin, esterase (C4), esterase lipase (C8), leucine arylamidase, naphthol-AS-BI-phosphohydrolase, trypsin and valine arylamidase. Cystine arylamidase, $\alpha$-fucosidase, $\alpha$ - and $\beta$-galactosidases, $\alpha$ - and $\beta$-glucosidases, $\beta$-glucuronidase, lipase (C14) and $\alpha$-mannosidase activities are not observed. The following compounds are used as sole carbon and energy sources: acetate, L-alanine, L-arginine, L-asparagine, L-aspartate, cellobiose, L-cysteine, gluconate, glucose, L-glutamate, L-glutamine, glycerol, L-histidine, myo-inositol, lactate, malate, maltose, L-ornithine, $\mathrm{D}$-salicin, L-serine, trehalose and L-valine. Acid is produced from cellobiose, glucose, myo-inositol, maltose and trehalose. Susceptible to ( $\mu$ g per disc unless otherwise stated) bacitracin (0.04 IU), cefoxitin (30), chloramphenicol (30), neomycin (30), nitrofurantoin (300), novobiocin (30), penicillin G (10 IU), rifampicin (5), streptomycin (10) and tobramycin (10), but not susceptible to amoxicillin (10), ampicillin (10), carbenicillin (100), cefotaxime (30), erythromycin (15), kanamycin (30), nystatin (100), polymyxin B (300 IU) or tetracycline (10). The predominant quinone is Q-10. The major polar lipids are phosphatidylglycerol and an unidentified glycolipid. Trace amounts of three unidentified glycolipids and 11 unidentified lipids are detected. The major fatty acids are iso- $\mathrm{C}_{17: 1} \omega 9 c$, iso- $\mathrm{C}_{15: 0}, \mathrm{C}_{16: 1} \omega 7 c$ and/or iso- $\mathrm{C}_{15: 0} 2-\mathrm{OH}$, $\mathrm{C}_{16: 0}$, iso- $\mathrm{C}_{17: 0}$ and $\mathrm{C}_{18: 1} \omega 7 c$; the major hydroxy fatty acids are iso- $\mathrm{C}_{17: 0} 3-\mathrm{OH}$ and $\mathrm{C}_{16: 0} 3-\mathrm{OH}$. The DNA G+C content of the type strain is $54.9 \mathrm{~mol} \%$ (HPLC).

The type strain, S3-22 $2^{\mathrm{T}}$ (=CGMCC $1.9109^{\mathrm{T}}=\mathrm{JCM}$ $16261^{\mathrm{T}}$ ), was isolated from a sediment sample collected from a ballast water tank.

\section{Acknowledgements}

We thank Jean Euzéby for his help with the specific etymology and nomenclature. We thank an anonymous reviewer for pointing out the abnormal quinone data. This work was supported by grants from the Zhejiang Provincial Natural Science Foundation of China (Y5080060), the Scientific Research Fund of the Second Institute of Oceanography, SOA (JT0906), the National Natural Science Foundation of China (40806066) and the Ministry of Science and Technology of China (973 Program, 2004CB719604-3; 863 Program, 2007AA021305).

\section{References}

Abraham, W.-R., Meyer, H., Lindholst, S., Vancanneyt, M. \& Smit, J. (1997). Phospho- and sulfolipids as biomarkers of Caulobacter sensu lato, Brevundimonas and Hyphomonas. Syst Appl Microbiol 20, 522539.

Abraham, W.-R., Strömpl, C., Meyer, H., Lindholst, S., Moore, E. R. B., Christ, R., Vancanneyt, M., Tindall, B. J., Bennasar, A. \& other authors (1999). Phylogeny and polyphasic taxonomy of Caulobacter species. Proposal of Maricaulis gen. nov. with Maricaulis maris (Poindexter) comb. nov. as the type species, and emended description of the genera Brevundimonas and Caulobacter. Int J Syst Bacteriol 49, 1053-1073. 
Chun, J., Lee, J.-H., Jung, Y., Kim, M., Kim, S., Kim, B. K. \& Lim, Y.-W. (2007). EzTaxon: a web-based tool for the identification of prokaryotes based on $16 \mathrm{~S}$ ribosomal RNA gene sequences. Int J Syst Evol Microbiol 57, 2259-2261.

Dadhwal, M., Jit, S., Kumari, H. \& Lal, R. (2009). Sphingobium chinhatense sp. nov., a hexachlorocyclohexane $(\mathrm{HCH})$-degrading bacterium isolated from an $\mathrm{HCH}$ dumpsite. Int $J$ Syst Evol Microbiol 59, 3140-3144.

Dong, X.-Z. \& Cai, M.-Y. (2001). Determinative Manual for Routine Bacteriology. Beijing: Scientific Press (English translation).

Drake, L. A., Doblin, M. A. \& Dobbs, F. C. (2007). Potential microbial bioinvasions via ships' ballast water, sediment, and biofilm. Mar Pollut Bull 55, 333-341.

Felsenstein, J. (1981). Evolutionary trees from DNA sequences: a maximum likelihood approach. J Mol Evol 17, 368-376.

Fitch, W. M. (1971). Toward defining the course of evolution: minimum change for a specific tree topology. Syst Zool 20, 406-416.

Grossi, G., Bargossi, A. M., Fiorella, P. L., Piazzi, S., Battino, M. \& Bianchi, G. P. (1992). Improved high-performance liquid chromatographic method for the determination of coenzyme Q10 in plasma. J Chromatogr A 593, 217-226.

Jeon, Y.-S., Chung, H., Park, S., Hur, I., Lee, J.-H. \& Chun, J. (2005). jPHYDIT: a JAVA-based integrated environment for molecular phylogeny of ribosomal RNA sequences. Bioinformatics 21, 3171-3173.

Kates, M. (1986). Techniques of Lipidology, 2nd edn. Amsterdam: Elsevier.

Kimura, M. (1980). A simple method for estimating evolutionary rates of base substitutions through comparative studies of nucleotide sequences. J Mol Evol 16, 111-120.

Kuykendall, L. D., Roy, M. A., O’Neill, J. J. \& Devine, T. E. (1988). Fatty acids, antibiotic resistance, and deoxyribonucleic acid homology groups of Bradyrhizobium japonicum. Int J Syst Bacteriol 38, 358-361.

Kwon, K. K., Lee, H. S., Yang, S. H. \& Kim, S. J. (2005). Kordiimonas gwangyangensis gen. nov., sp nov., a marine bacterium isolated from marine sediments that forms a distinct phyletic lineage (Kordiimonadales ord. nov.) in the 'Alphaproteobacteria'. Int J Syst Evol Microbiol 55, 2033-2037.

Leifson, E. (1963). Determination of carbohydrate metabolism of marine bacteria. J Bacteriol 85, 1183-1184.
Marmur, J. (1961). A procedure for the isolation of deoxyribonucleic acid from microorganisms. J Mol Biol 3, 208-218.

Mesbah, M. \& Whitman, W. B. (1989). Measurement of deoxyguanosine/thymidine ratios in complex mixtures by high-performance liquid chromatography for determination of the mole percentage guanine + cytosine of DNA. J Chromatogr A 479, 297-306.

Mikhailov, V. V., Romanenko, L. A. \& Ivanova, E. P. (2006). The genus Alteromonas and related proteobacteria. In The Prokaryotes: a Handbook on the Biology of Bacteria, 3rd edn, vol. 6, pp. 597-645. Edited by M. Dworkin, S. Falkow, E. Rosenberg, K. H. Schleifer \& E. Stackebrandt. New York: Springer.

Poindexter, J. S. (2005). Genus I. Caulobacter Henrici and Johnson 1935b, $83^{\mathrm{AL}}$ emend. Abraham, Strömpl, Meyer, Lindhorst, Moore, Christ, Vancanneyt, Tindall, Bennasar, Smit and Tresar, 1999, 1070. In Bergey's Manual of Systematic Bacteriology, 2nd edn, vol. 2C, pp. 287-303. Edited by D. J. Brenner, N. R. Krieg, J. T. Staley \& G. M. Garrity. New York: Springer.

Saitou, N. \& Nei, M. (1987). The neighbor-joining method; a new method for reconstructing phylogenetic trees. Mol Biol Evol 4, 406-425.

Stackebrandt, E. \& Goebel, B. M. (1994). Taxonomic note: a place for DNA-DNA reassociation and $16 \mathrm{~S}$ rRNA sequence analysis in the present species definition in bacteriology. Int J Syst Bacteriol 44, 846849.

Tamura, K., Dudley, J., Nei, M. \& Kumar, S. (2007). MEGA4: molecular evolutionary genetics analysis (MEGA) software version 4.0. Mol Biol Evol 24, 1596-1599.

Xu, X.-W., Wu, Y.-H., Zhou, Z., Wang, C.-S., Zhou, Y.-G., Zhang, H.-B., Wang, Y. \& Wu, M. (2007). Halomonas saccharevitans sp. nov., Halomonas arcis sp. nov. and Halomonas subterranea sp. nov., halophilic bacteria isolated from hypersaline environments of China. Int J Syst Evol Microbiol 57, 1619-1624.

Xu, X.-W., Wu, Y.-H., Wang, C.-S., Yang, J.-Y., Oren, A. \& Wu, M. (2008). Marinobacter pelagius sp. nov., a moderately halophilic bacterium. Int J Syst Evol Microbiol 58, 637-640.

Xu, X.-W., Wu, Y.-H., Wang, C.-S., Wang, X.-G., Oren, A. \& Wu, M. (2009). Croceicoccus marinus gen. nov., sp. nov., a yellow-pigmented bacterium from deep-sea sediment, and emended description of the family Erythrobacteraceae. Int J Syst Evol Microbiol 59, 2247-2253.

ZoBell, C. E. (1941). Studies on marine bacteria. I. The cultural requirements of heterotrophic aerobes. J Mar Res 4, 42-75. 